\title{
AUTOMATION OF THE SMART HOUSE SYSTEM-LEVEL DESIGN
}

\author{
Vasyl Teslyuk ${ }^{1}$, Vasyl Beregovskyi ${ }^{2}$, Andrii Pukach ${ }^{1}$ \\ ${ }^{1}$ Lviv Polytechnic National University, CAD Department, ${ }^{2}$ College of Electronic Devices of the Ivano-Frankivsk National Technical University of Oil and Gas
}

Abstract. In the article the smart house (SH) structural scheme, the general performance algorithm of the SH system, and the SH system model based on colored Petri nets, which enables exploring dynamics of the whole system as well as internal interaction of its main structural and functional subsystems at the system level design, have been developed.

Keywords: smart house, automation, design, system, colored Petri nets

\section{AUTOMATYZACJA SYSTEMOWEGO POZIOMU PROJEKTOWANIA INTELIGENTNEGO DOMU}

Streszczenie. W artykule przedstawiono opracowanie schematu strukturalnego inteligentnego domu (ID), ogólny algorytm pracy systemu ID, a także model systemu ID na podstawie kolorowej sieci Petri, co pozwala badać dynamikę zachowania zarówno całego systemu ID, jak $i$ wewnętrznego współdziałania jej głównych podsystemów.

Słowa kluczowe: inteligentny dom, automatyzacja, projektowanie, system, kolorowe sieci Petri

\section{Introduction}

The energy saving issues becomes more and more argent in recent days all over the world [15]. One of the possible partial solution to this problem is a widespread use of the smart house technologies $(\mathrm{SH})[19]$ that enables saving energy consumption up to $30 \%-40 \%$ and even more [15]. This technology is named differently: smart house, intelligent, obedient, energy-efficient house and others $[2,6,11]$, but the core is a hardware-software system, which ensures comfortable accommodations and possibility of substantial energy savings.

Nowadays there are a lot of companies, which offer modules ready for the implementation of this project $[2,6,11,19]$ and there are many design solutions of smart houses and theirs components $[1,5,8,21,23,24]$.

Various systems for domestic appliances control via the Internet and mobile phones have been created and implemented [19].

Smart houses design as well as the majority of complex technical systems requires application of the block-hierarchical approach [22], which includes such hierarchical levels, namely: system level, subsystems and elements levels. For the analysis of smart house systems and subsystems performance models based on Petri theory $[3,4,6,9,10,16]$, which enables integrating different functional components and investigate their joint work, are proposed to be used.

The purpose of the research is the development of the $\mathrm{SH}$ system model that provides automation of the inner system processes and the relationship of its main subsystems on the system design level.

\section{Development of the SH system model}

To ensure the maximum efficiency and functionality, the smart house system should include the following major subsystems: climate-control subsystem, lighting and domestic appliances subsystem, safety and security subsystems and number of other additional subsystems [1, 5, 8, 19, 21, 23, 24].

In order to ensure an effective synchronization mechanism among the main subsystems and components of the developed $\mathrm{SH}$ system as well as with the user, the SH system should also include the remote SH controls, the inner SH control module, the central management module and SH subsystems controllers. Taking into account the above comopnents the structural SH system scheme, presented in Fig. 1 has been developed.

The developed structural scheme of the SH system (Fig. 1) includes several major subsystems, namely, climate-control subsystem, lighting and domestic appliances subsystems, safety and security subsystems as well as the monitoring subsystem. Each of the subsystems is responsible for the instant response to the sensors triggering, indicating the change of the corresponding input SH system parameter, with the aim of the further correction of the system in a given area (areas). Data exchange between the major functional components of the SH system is done through the internal network (Fig. 1).

The system can operate in three modes - in automatic mode, user mode and in the standby mode. In the automatic mode the SH system oversees a response to the change of any input system parameter and running mechanism of the system correction using the appropriate controller (Fig. 1) in automatic mode, and the user is only receiving informational messages about system changes.

The user mode provides synchronization of the $\mathrm{SH}$ system with the user through the central management module and remote SH controls using intranet (wired or wireless LAN) or an appropriate Internet connection (Fig. 1).

During this in case of any input parameters changes the corresponding subsystem is activated and the monitoring subsystem forms the information message that requests the user to activate the necessary mechanism for the system correction. Thus, the system correction mechanism is launched exclusively with the user`s consent.

The standby mode is intended to temporary suspend (turn off) the SH system performance.

Correction of the SH system is carried out with the use of the appropriate controller (s) (Fig. 1), and actuators.

Each SH subsystem includes the number of individual input and output parameters, sensors and actuators, and is designed for monitoring and correction of the specific $\mathrm{SH}$ area.

Sensors are responsible for the collecting input information on the system state, while the actuators are responsible for the implementation of the system correction mechanism in the desired direction.

According to the developed structural scheme (Fig. 1), the general SH system algorithm is presented in the Fig. 2. At the very beginning the system goes into the automatic mode. In case of any event (activation of one or more input parameters) the according associative link of the activated input parameters reference to their domain subsystems and launch of such subsystems are set. In the selected automatic mode the neurcontroler is run $[7,13,14,17,20,25]$, which activates the mechanism required for the according $\mathrm{SH}$ system parameters correction.

In the user mode the system generates the appropriate request and pends the user permission confirmation to perform the required $\mathrm{SH}$ parameters correction, in case of confirmation the neurcontroller is run. After this the system switches to its start state expecting events, or goes into the standby mode and temporary suspension of the system operation.

On the base of the proposed algorithm the SH system model based on colored Petri nets [1-8, 1-9], presented below in Fig. 3, has been developed. 


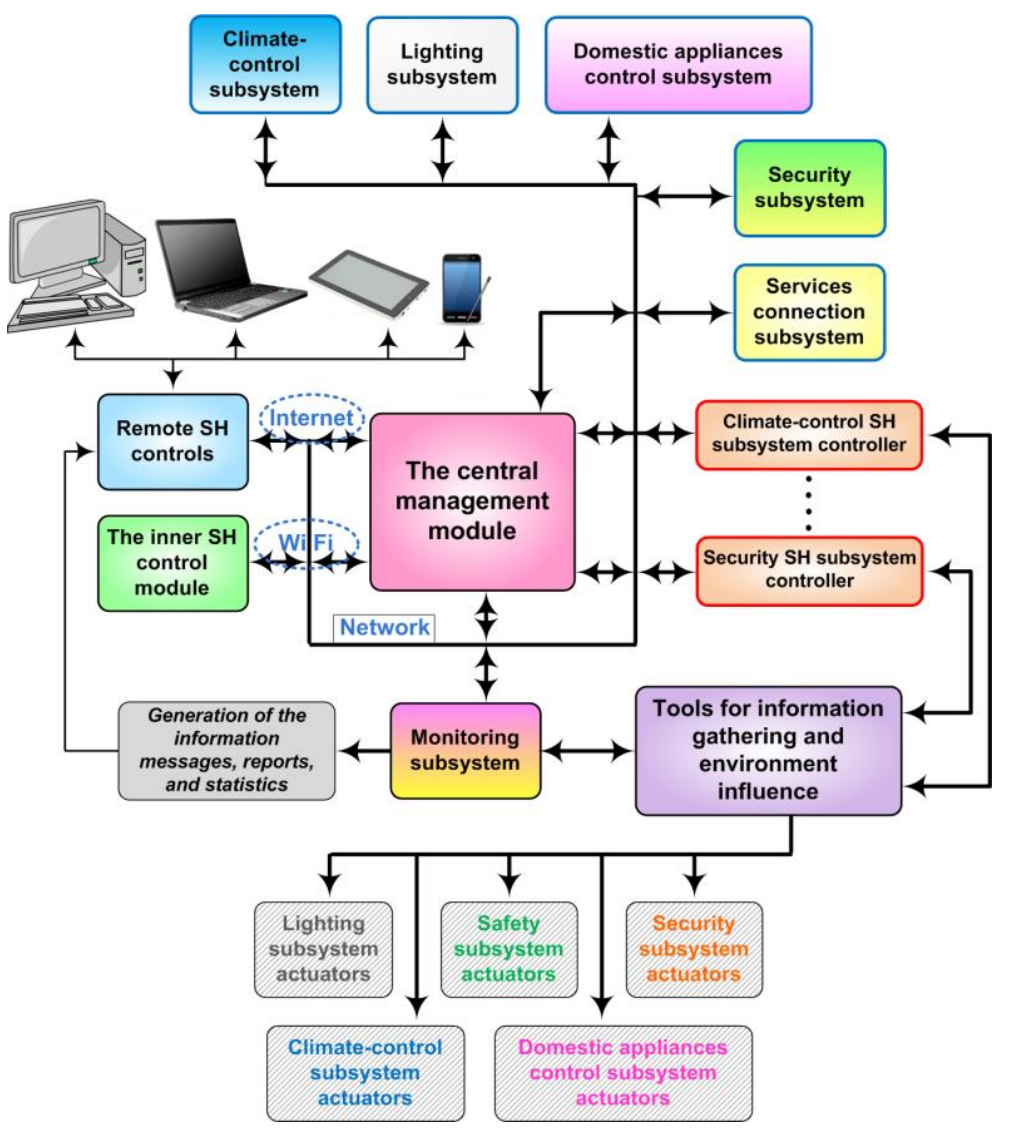

Fig. 1. Structural scheme of the smart house system
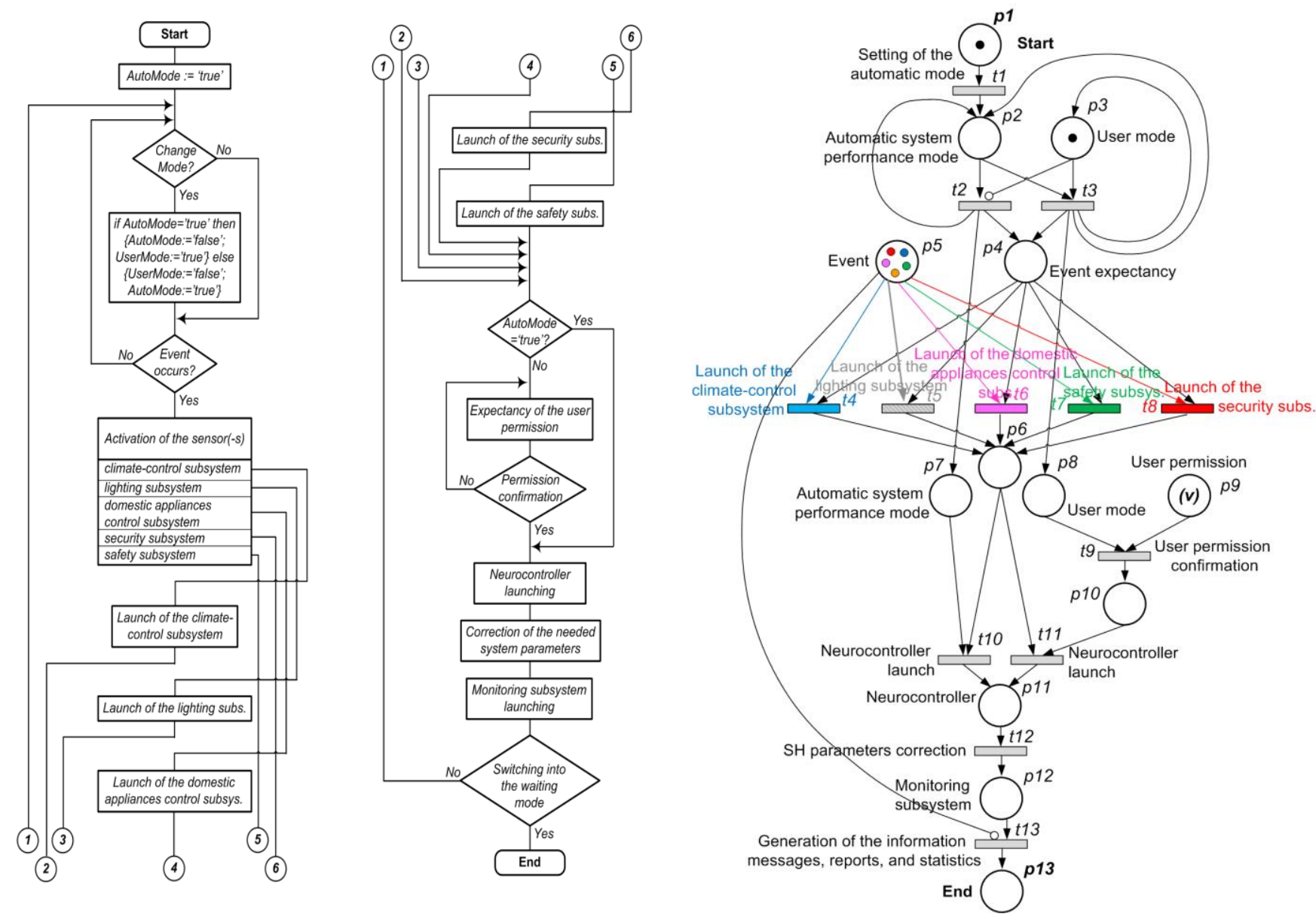


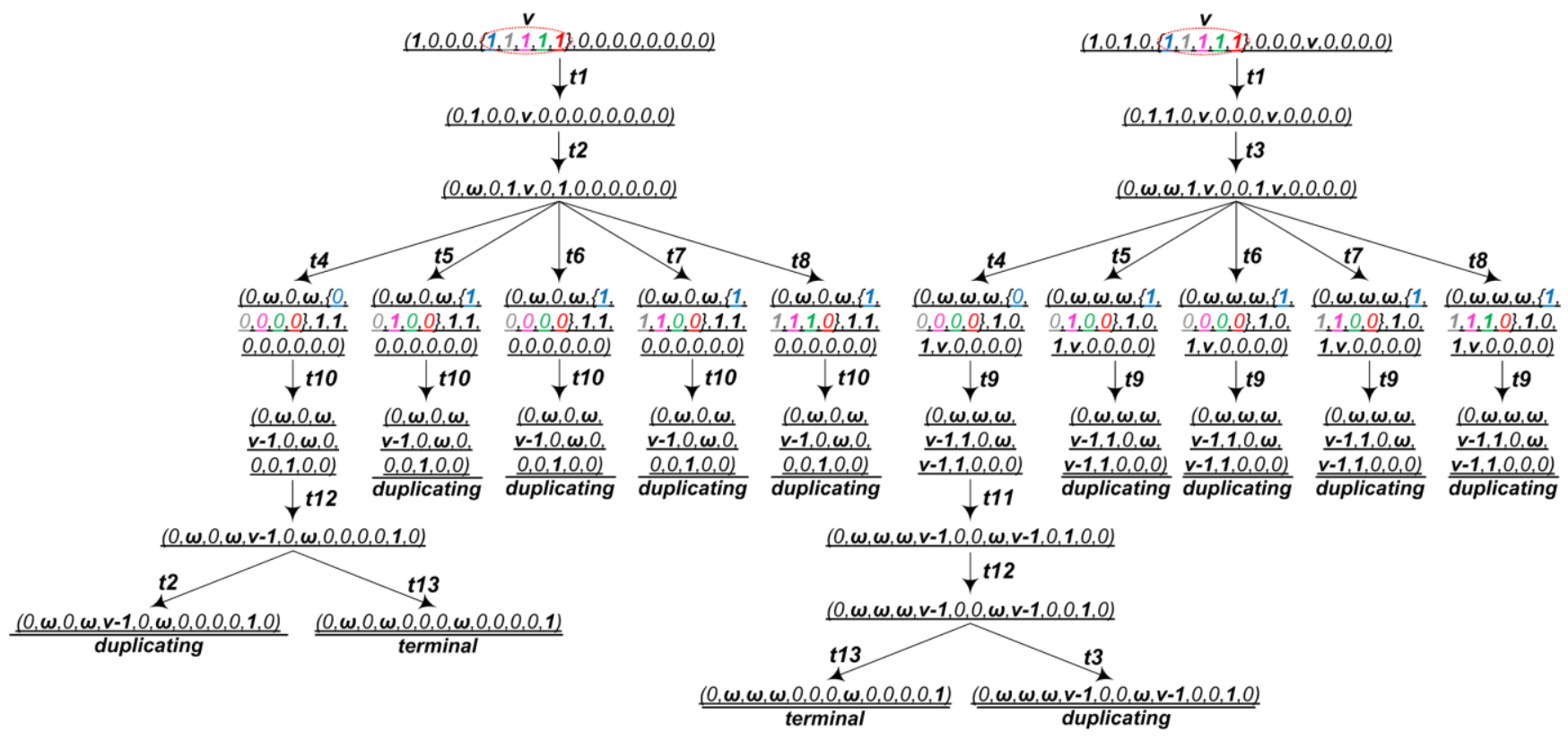

Fig. 4. The state reach graph developed on the base of colored Petri nets SH model

Table 1. The SH model based on colored Petri nets states and their primary purpose

\begin{tabular}{|c|c|c|}
\hline No. & State e & Purpose \\
\hline $\mathrm{p} 1$ & Beginning & $\begin{array}{l}\text { The state is responsible for launching the } \\
\text { model, placing a marker at this position starts } \\
\text { the work }\end{array}$ \\
\hline $\mathrm{p} 2$ & $\begin{array}{c}\text { The automatic } \\
\text { mode of the } \mathrm{SH} \\
\text { system }\end{array}$ & $\begin{array}{l}\text { The marker state in this position affirms the } \\
\text { automatic operation mode of the SH system }\end{array}$ \\
\hline p3 & $\begin{array}{l}\text { The user mode of } \\
\text { the SH system }\end{array}$ & $\begin{array}{l}\text { The marker state in this position affirms } \\
\text { choice of the user mode of the SH system }\end{array}$ \\
\hline $\mathrm{p} 4$ & $\begin{array}{c}\text { Events } \\
\text { expectancy }\end{array}$ & $\begin{array}{l}\text { The marker in this position indicates a } \\
\text { readiness to identify the active system events }\end{array}$ \\
\hline p5 & Event & $\begin{array}{l}\text { The "event shop" state. This position } \\
\text { includes the active events markers that } \\
\text { emerged in the different SH subsystems }\end{array}$ \\
\hline p6 & $\begin{array}{l}\text { Readiness to } \\
\text { launch the } \\
\text { neurocontroller }\end{array}$ & $\begin{array}{l}\text { The marker in this position indicates the } \\
\text { system readiness to launch the mechanism of } \\
\text { the SH system parameters correction }\end{array}$ \\
\hline $\mathrm{p} 7$ & $\begin{array}{l}\text { The automatic } \\
\text { mode of the } \\
\text { system }\end{array}$ & $\begin{array}{c}\text { The marker in this position indicates the } \\
\text { selected automatic mode of the system } \\
\text { operation and the subsequent neurocontroller } \\
\text { launching }\end{array}$ \\
\hline p8 & The user mode & $\begin{array}{l}\text { The marker in this position affirms the } \\
\text { selected user mode of the SH system and } \\
\text { waiting for the user permission confirmation } \\
\text { to perform the correction of the SH system }\end{array}$ \\
\hline $\mathrm{p} 9$ & $\begin{array}{l}\text { The user } \\
\text { permission }\end{array}$ & $\begin{array}{l}\text { The marker in this position indicates the user } \\
\text { acquaintance with the necessity of making } \\
\text { SH system parameters correction in the } \\
\text { selected fields and his or her permission to } \\
\text { run the neurocontroller }\end{array}$ \\
\hline p10 & $\begin{array}{l}\text { Confirmation of } \\
\text { the user } \\
\text { permission }\end{array}$ & $\begin{array}{l}\text { The marker in this position affirms the } \\
\text { selected user mode of the SH system and the } \\
\text { subsequent launch of the neurocontroller }\end{array}$ \\
\hline p11 & Neurocontroller & $\begin{array}{l}\text { The marker in this position indicates the } \\
\text { successful neurocontroller launching and } \\
\text { moving to the required system parameter } \\
\text { correction phase }\end{array}$ \\
\hline $\mathrm{p} 12$ & $\begin{array}{l}\text { The monitoring } \\
\text { subsystem }\end{array}$ & $\begin{array}{l}\text { The marker in this position affirms the launch } \\
\text { of the SH system monitoring subsystem }\end{array}$ \\
\hline p13 & End & $\begin{array}{l}\text { The marker in this position indicates the } \\
\text { successful completion of the model } \\
\text { performance }\end{array}$ \\
\hline
\end{tabular}

Description and purpose of the developed model states and transition are presented below in table 1 and table 2, respectively.

As according to the proposed $\mathrm{SH}$ system block diagram (Fig. 1), the system has a number of structural and functional subsystems with different functional purposes, in order to prevent any conflict situations among subsystems, there is a strict levels hierarchy (from the first to fifth, where the 1st has the highest priority) of the basic functional SH subsystems. It is presented below in table 3 .

Table 2. The SH model based on colored Petri nets transitions and their primary purpose

\begin{tabular}{|c|c|}
\hline No. & Purpose \\
\hline $\mathrm{t} 1$ & The launch of the model \\
\hline $\mathrm{t} 2$ & Setting of the SH system automatic operation mode \\
\hline $\mathrm{t} 3$ & Setting of the SH system user mode \\
\hline $\mathrm{t} 4$ & The launch of the climate-control SH subsystem \\
\hline $\mathrm{t} 5$ & The launch of the lighting SH subsystems \\
\hline t6 & $\begin{array}{c}\text { The launch of the domestic appliance control SH } \\
\text { subsystem }\end{array}$ \\
\hline $\mathrm{t} 7$ & The launch of the safety SH subsystem \\
\hline $\mathrm{t} 8$ & The launch of the security SH subsystem \\
\hline $\mathrm{t} 9$ & $\begin{array}{c}\text { Confirmation of the user permission to launch the } \\
\text { neurocontroller for the indicated SH parameters } \\
\text { correction }\end{array}$ \\
\hline $\mathrm{t} 10$ & Launch of the neurocontroller (in the automatic mode) \\
\hline $\mathrm{t} 11$ & Launch of the neurocontroller (in the user mode) \\
\hline $\mathrm{t} 12$ & SH parameters correction \\
\hline $\mathrm{t} 13$ & $\begin{array}{c}\text { Generation of the information messages, reports, and } \\
\text { statistics }\end{array}$ \\
\hline
\end{tabular}


Table 3. The priority levels hierarchy of the basic functional SH subsystems

\begin{tabular}{|c|c|}
\hline Subsystem & Priority level \\
\hline The security subsystem & 1 \\
\hline The safety subsystem & 2 \\
\hline The lighting subsystem & 3 \\
\hline The domestic appliance management subsystem & 4 \\
\hline The climate-control subsystem & 5 \\
\hline
\end{tabular}

Thus, according to the proposed hierarchy, the security subsystem has the highest priority, which is responsible for the material values saving and general protection of the $\mathrm{SH}$ system against the unauthorized penetration and external influence. In the same time, the climate control subsystem has the lowest priority, primarily due to the high inertia to change the basic parameters of the subsystem. The state reach graph developed on the base of colored Petri nets SH model is depicted below in Fig. 4. Each link of the graph corresponds to a possible state of the developed model. So, built graph represents the reachability of each of the states of the developed model based on colored Petri nets, and it allows to keep the full picture of the behavior of $\mathrm{SH}$ system, represented by the developed model, based on colored Petri nets.

\section{Conclusions}

The work presents the structural scheme of the SH system, the general algorithm of the $\mathrm{SH}$ system and the $\mathrm{SH}$ system model based on colored Petri nets. The developed structural scheme of the SH system includes a number of key structural and functional subsystems that allow implementing automatic correction of the basic SH parameters for the most comfortable inner climate conditions and maximum energy savings, while providing protection against intruders penetration into the $\mathrm{SH}$, as well as against probable property damage caused by emergency manmade situations (leak of the natural gas, water flowing, fire inside the SH premises, etc.) In order to avoid potential conflicts that may arise among the basic functional subsystems, there is a strict priority levels hierarchy in the SH system.

\section{References}

[1] Grynyk O., Denysyuk P., Teslyuk V.: System for Automation Testing Components of the Smart Home. Proc. of the VII-th Intern. Conf. of Computer Science \& Information Technologies 2012 (CSIT'2012). Lviv: Publishing House Vezha\&Co 2012, pp. 44 - 46

[2] Harper R.: Inside the Smart Home. London, Springer, August, 2003.

[3] James L. Peterson A.: Note on Colored Petri Nets, Information Processing Letters, Volume 11, Number 1, August 1980, p. 40-43.

[4] Jensen K., Kristensen L.M.: Coloured Petri Nets: modelling and validation of concurrent systems: 1st edition Springer, 2009.

[5] Kis Y.P., Teslyuk V. M.: Methods and tools of authentication biometric data in information systems, Actual Problems of Economics, 2012, № 12(138). p. $174-182$.

[6] Niezabitowska E.: Budynek inteligentny Tom I, II Potrzeby użytkownika a standard budynku inteligentnego, Wyd. Politechniki Śląskiej, Gliwice 2005.

[7] Rosenblatt F.: The Perceptron: A Probabilistic Model for Information Storage and Organization in the Brain, Cornell Aeronautical Laboratory, Psychological Review, v 65, No. 6, pp. 386-408.

[8] Teslyuk V., Beregovska C.: Schematic Model of Protection and Lighting Subsystems for Analysis of Intellectual House, Proc. of the XII Intern. Conf. on The Experience of Designing and Application of CAD Systems in Microelectronics (CADSM'2013). Lviv - Polyana, Ukraine, 2013. p. 436 - 437.

[9] Teslyuk V., Denysyuk P., Hamza Ali Yousef Al Shawabkeh, Kernytskyy A. Developing Information Model Of The Reachability Graph, Proc. of the XVth International Seminar, Workshop Of Direct And Inverse Problems O Electromagnetic And Acoustic Wave Theory (DIPED - 2010). Tbilisi, Georgia 2010 , p. $210-214$.
[10] Teslyuk V., Hamza Al-Shavabkeh, Pereyma M., Al Omari Tarik: The formalization of the MEMS automated design process by usage of Petri Networks. Proc.of the IIId International Conference of Young Scientists (MEMSTECH'2007) Lviv - Polyana, May, 23-26, 2007, p. 133 - 134.

[11]Гірник М.А.: Інтелектуальна споруда - інтегрована інформаційна система http://www.dabi.gov.ua

[12] Котов В.Е. Сети Петри. М.: Наука, 1984

[13] Омату С., Халид М., Юсоф Р.: Нейроуправление и его приложения, пер. с англ, М: ИПРЖР, 2000.

[14] Осовский С.: Нейронные сети для обработки информации Пер. с польского И.Д. Рудинского, М: Финансы и статистика, 2002.

[15]Перспективи ринку систем Розумний будинок: http://alls.in.ua/17818-perspektivi-rinku-sistem-rozumnijj-budinok.html

[16]Питерсон Дж.: Теория сетей Петри и моделирование систем. М. Мир, 1984

[17] Розенблатт, Ф.: Принципы нейродинамики: Перцептроны и теория механизмов мозга, Principles of Neurodynamic: Perceptrons and the Theory of Brain Mechanisms, М.: Миp, 1965.

[18] Ротач В. Я.: Теория автоматического управления, М.: Издательский дом МЭИ, 2008.

[19] Системи безпеки Інтелектуального будинку: http://dim.promotion-soft.com/bud-remont-2012-07-07-5508/

[20]Стюарт Р., Норвиг П.: Искусственный интеллект: современный подход, 2-е изд.: Пер. с англ, М. : Издательский дом, Вильяме, 2006.

[21]Теслюк В.М., Березький О.М., Береговський В.В., Теслюк Т.В. Розроблення нейроконтролера для управління підсистемою освітлення інтелектуального будинку, Зб. наук. пр. ІППМЕ ім.Г.Є.Пухова НАН України. Київ, 2012, Вип. 64, с.137 - 143.

[22]Теслюк В.М., Денисюк П.Ю.: Автоматизація проектування мікроелектромеханічних систем на компонентному рівні: Монографія. Львів: Видавництво Львівської політехніки, 2011.

[23] Теслюк В.М., Денисюк П.Ю., Теслюк Т.В., Береговський В.В.: Програмноапаратна реалізація нейроконтролера для підсистеми клімат контролю інтелектуального будинку, Тези доповідей VI Міжнародної науковопрактичної конференції Сучасні проблеми i досягнення в галузі радіотехніки, телекомунікацій та інформаційних технологій. Запоріжжя: ЗНТУ, 2012. c. $211-212$

[24]Теслюк В.М., Теслюк Т.В., Ляпандра А.С.: Модель підсистеми клімат контролю для аналізу роботи інтелектуального будинку, 3б. наук.-техн. пр.: Науковий Вісник НЛТУ України. 2012. Вип. 22.9, с. 132 - 135.

[25] Хайкин С.: Нейронные сети: полный курс, Neural Networks: A Comprehensive Foundation. 2-е изд., М.: Вильямс, 2006.

\section{Vasyl Teslyuk \\ e-mail: vtesliuk@polynet.lviv.ua \\ Professor of CAD department. Research interests: Computer aided design and modeling of microelectromechanical systems and integrated circuits.}

Ans

\section{Andii Pukach}

e-mail: andrey_pukach@mail.ru

Junior Research Fellow of research group DB/SEB. Research interests: Microelectromechanical systems.
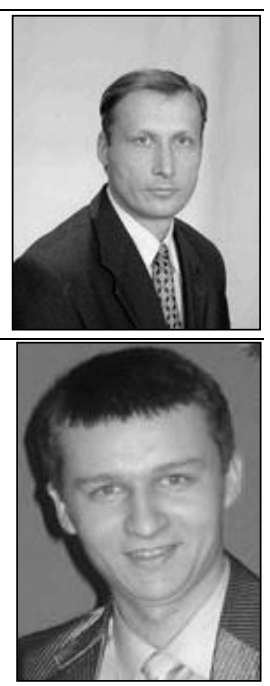

Vasyl Beregovsky
e-mail: bvasylv@mail.

Teacher of higher category of College of electronic devices of the Ivano-Frankivsk national technical university of oil and gas. Research interests: Microcircuitry; microsystems; digital technique; computing and microprocessor devices at electronic vehicles, computer circuit technology; technological practice, architecture of the computer systems and networks.

otrzymano/received: 23.10 .2013 przyjęto do druku/accepted: 20.11 .2013

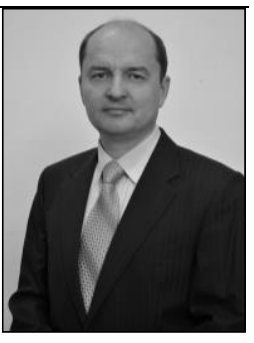

